\title{
Synthesis and photo-physical properties of fluorescence molecular probe for turn-ON type detection of cytosine bulge DNA
}

\author{
Rajiv Kumar Verma, ${ }^{\dagger}$ Fumie Takei ${ }^{\S}$ and Kazuhiko Nakatani ${ }^{\dagger, *}$
}

${ }^{\dagger}$ Department of Regulatory Bioorganic Chemistry, The Institute of Scientific and

Industrial Research, Osaka University, Mihogaoka, 8-1, Ibaraki, Osaka, JAPAN:

567-0047

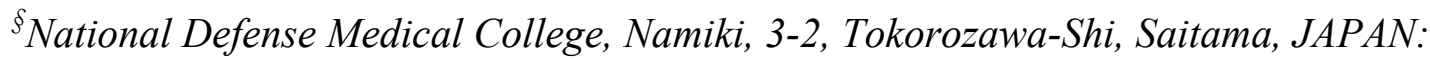
359-8513

\section{Supporting Information}

\begin{tabular}{|c|c|c|}
\hline & Content: & Pages \\
\hline 1. & Material and methods & S2-S4 \\
\hline 2. & Synthetic scheme and spectroscopic characterization data & S4-S9 \\
\hline 3. & Absorption spectra of PyDANP from $85^{\circ} \mathrm{C}$ to $2^{\circ} \mathrm{C}$ & S9 \\
\hline 4. & Absorption spectra of PyDANP at different methanol percentages & S9 \\
\hline 5. & Fluorescence spectra of PyDANP, PyL and DANP & S10 \\
\hline 6. & Concentration dependent absorption spectra of PyDANP & S10 \\
\hline 7. & Concentration dependent fluorescence spectra of PyDANP & S11 \\
\hline 8. & Concentration dependent absorption and fluorescence spectra of PyL & S11 \\
\hline 9. & Concentration dependent absorption and fluorescence spectra of DANP & S12 \\
\hline 10. & $\begin{array}{l}\text { Concentration dependent absorption and fluorescence spectra of PyL }+ \\
\text { DANP }\end{array}$ & S12 \\
\hline 11. & Absorption spectra of ligand PyL in presence of c-bulge hairpin DNA & S13 \\
\hline 12. & References & S13 \\
\hline 13. & Copies of NMR spectra for compound characterization & S14-S18 \\
\hline
\end{tabular}




\section{Material and methods:}

General: Solvents and starting materials were purchased by the standard suppliers and used without further purification. Analytical thin layer chromatography (TLC) was performed on $0.2 \mathrm{~mm}$ silica 60 coated on plates with F254 indicator. Flash column chromatography was performed on Wako gel C-200 silica gel. High performance liquid chromatography (HPLC) was performed by a Gilson 811C Dynamic Mixer system with a UV detector set at $254 \mathrm{~nm}$ using a Cosmosil $5 \mathrm{C}_{18}$-MSII column $(150 \times 20 \mathrm{~mm})$ with a dual solvent system of $0.1 \% \mathrm{HOAc} / \mathrm{H}_{2} \mathrm{O}$ (Solvent A) and acetonitrile (Solvent B). ${ }^{1} \mathrm{H}$ and ${ }^{13} \mathrm{C}$ NMR data were recorded on JEOL ECS400 and JEOL ECS600 spectrometers. Chemical shifts were reported in parts per million (ppm) and coupling constants $(J)$ were reported in hertz. High-resolution mass spectra were recorded on a Thermo LTQ Orbitrap XL mass spectrometer in electron spray ionization mode.

\footnotetext{
Absorption and Fluorescence spectra measurements: All absorption and fluorescence spectra were measured with c-bulge hairpin DNA (5'GTCAXCYACAACTTTTGTTGTZ_WTGAC-3') containing different flanking base pairs such as TCA/T_A and GCG/C_C. Full matched DNA used in this study have 5'GTCAGCACAACTTTTGTTGTGCTGAC-3' sequences. All the DNA samples were prepared in $10 \mathrm{mM}$ sodium cacodylate buffer of $\mathrm{pH} 7.0$ containing $100 \mathrm{mM} \mathrm{NaCl}$. DNA and ligand solutions were mixed to give a final concentration of $10 \mu \mathrm{M}$ each. UV spectra were recorded on a SHIMADZU DU800 spectrophotometer using a quartz cell. Fluorescence spectra were recorded on a JASCO FP-8500 spectrometer. Excitation wavelength for the fluorescent measurements was the wavelength with the maximum absorption unless otherwise noted.
} 
Temperature dependent absorption spectra measurement: Temperature dependent absorption spectra were measured with SHIMADZU UV-2550 UV-Vis spectrometer linked to a Peltier temperature controller. The absorbance of the sample was monitored at $260 \mathrm{~nm}$ from 2 to $85{ }^{\circ} \mathrm{C}$ with a heating rate of $1{ }^{\circ} \mathrm{C} / \mathrm{min} .10 \mu \mathrm{M}$ ligand sample was prepared in $10 \mathrm{mM}$ sodium cacodylate buffer of $\mathrm{pH} 7.0$ containing $100 \mathrm{mM} \mathrm{NaCl}$.

Absorption and emission spectra in methanol: UV spectra were recorded on a SHIMADZU DU800 spectrophotometer using a quartz cell. Fluorescence spectra were recorded on a JASCO FP-8500 spectrometer. The methanol percentages were varied by adding required volume of HPLC grade methanol, $100 \mu \mathrm{M}$ aqueous solution of ligand, $100 \mathrm{mM}$ sodium cacodylate buffer, $1 \mathrm{M} \mathrm{NaCl}$ solution and required volume of milliQ water to make the final solution conditions at $10 \mu \mathrm{M}$ ligand and $10 \mathrm{mM}$ sodium cacodylate buffer with $100 \mathrm{mM} \mathrm{NaCl}$.

Fluorescence quantum yield measurement: Quantum Yield measurements were carried out on Hamamatsu C9920-01 Absolute PL quantum yield measurement system. Quantum yields were measured with $20 \mu \mathrm{M}$ DNA in $10 \mathrm{mM}$ sodium cacodylate buffer ( $\mathrm{pH}$ 7.0) containing $100 \mathrm{mM} \mathrm{NaCl}$. The DNA sequences are same as used in UV and fluorescence measurements. The concentration of each ligand was fixed at $10 \mu \mathrm{M}$. The excitation wavelength was $375 \mathrm{~nm}$ for ligand only and $390 \mathrm{~nm}$ for samples containing cytosine bulge DNA.

CSI-TOF-MS measurement: CSI-TOF MS data were measured on AccuTOF LP 4G Time-of-Flight Mass Spectrometer from JEOL. C-bulge hairpin oligonucleotide (TCA/T_A) used in this study has 5'-GTCATCAACAACTTTTGTTGTT_ATGAC3') sequence. Samples were prepared as 1:1 mixture of water and methanol containing 
$50 \mathrm{mM}$ ammonium acetate. The final conc. of oligonucleotides and ligand PyDANP were fixed at $10 \mu \mathrm{M}$ and $20 \mu \mathrm{M}$ respectively.

\section{Synthesis of ligand PyDANP:}
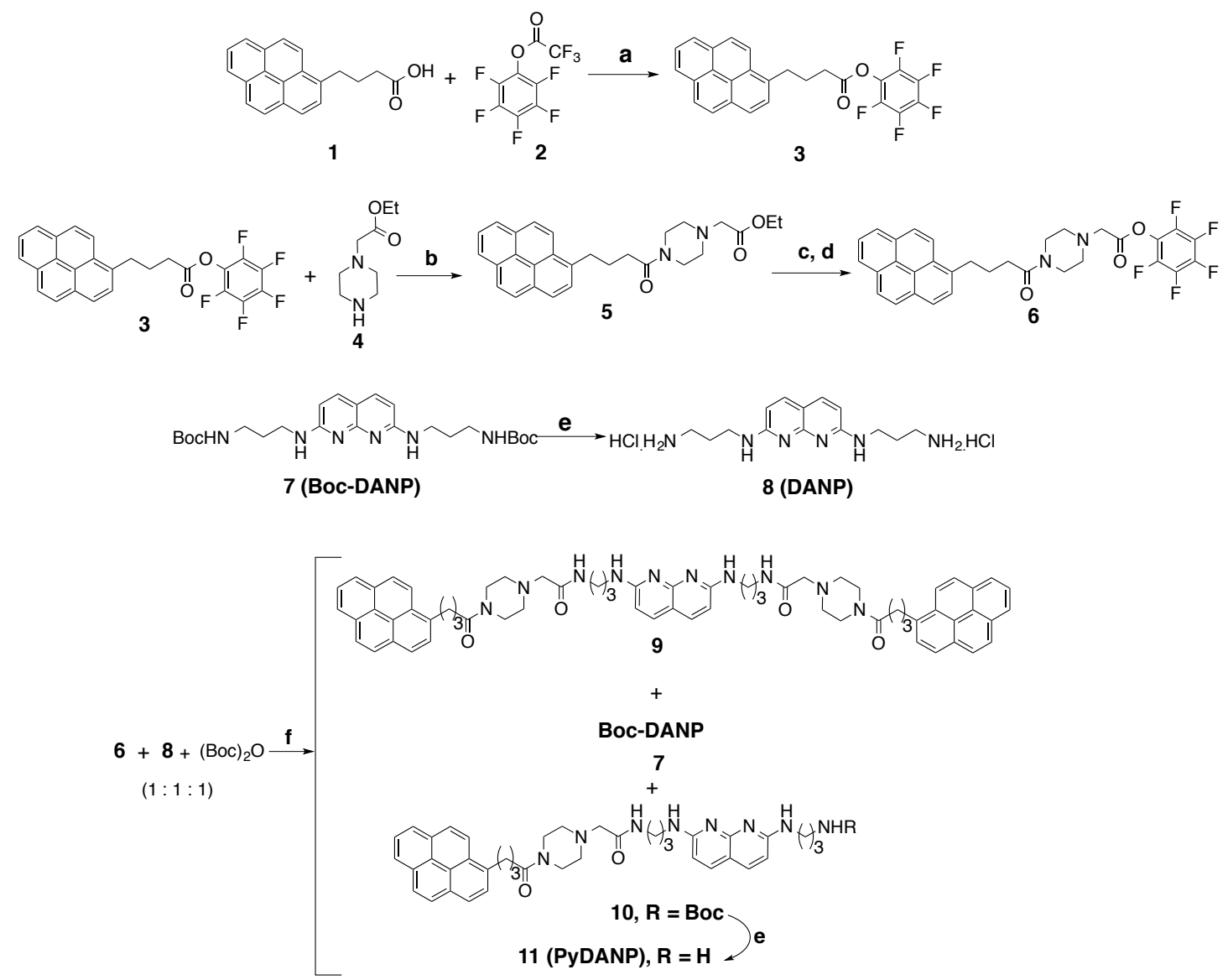

Figure S1: Synthetic scheme for PyDANP: a) Triethylamine / dichloromethane / r.t. / 12h, 89\%; b) Diisopropylethylamine / dichloromethane / r.t. / $2.5 \mathrm{~h}, 86 \%$; c) methanolic sodium hydroxide / dichloromethane / r.t. / 2h; d) pentafluorophenyl trifluoroacetate / triethylamine / dimethylformamide / r.t. / 3h, 80\%; e) $4 \mathrm{M} \mathrm{HCl}$ in ethylacetate / dichloromethane / r.t. / 3h, quantitative Diisopropylethylamine / dimethyl formamide:dichloromethane $(1: 4)$ / r.t. / 4h, 30\%; f) Diisopropylethylamine / dimethyl formamide:dichloromethane (1:4) / r.t. / 4h, 30\%;

Perfluorophenyl 4-(pyren-1-yl)butanoate $3:{ }^{1}$ Pyrene-1-butanoic acid 1 (2.5 mmol,

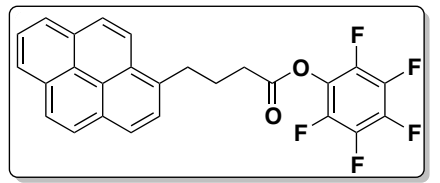

$0.73 \mathrm{~g})$ was dissolved in dichloromethane $(15 \mathrm{~mL})$ and 3 equivalents of triethylamine $(7.5 \mathrm{mmol}, 1.05 \mathrm{~mL})$ was

added to it. The reaction mixture was stirred at room temperature and 3 equivalent of petafluorophenyl trifluoroactetate $2(7.5 \mathrm{mmol}, 1.29 \mathrm{~mL})$ was added in a dropwise manner. The reaction mixture was stirred until completion of reaction (12 hrs, monitored by TLC). The reaction mixture was diluted with dichloromethane and 
washed with water $(2 \times 15 \mathrm{~mL})$. The organic extracts were dehydrated with anhydrous sodium sulfate and evaporated to give crude product. The compound was purified by column chromatography using $15 \%$ chloroform in hexane to give white solids (1.01 g, 89\%). ${ }^{1} \mathrm{H}$ NMR ( $\left.\mathrm{CDCl}_{3}, 400 \mathrm{MHz}\right): \delta=8.29$ (d, $\left.J=9.2 \mathrm{~Hz}, 1 \mathrm{H}\right), 8.19$ 8.12 (cluster, 4H), 8.04 (s, 2H), $8.00(\mathrm{t}, J=7.6 \mathrm{~Hz}, 1 \mathrm{H}), 7.88$ (d, $J=8.0 \mathrm{~Hz}, 1 \mathrm{H}), 3.49$ (t, $J=7.2 \mathrm{~Hz}, 2 \mathrm{H}), 2.79(\mathrm{t}, J=7.2 \mathrm{~Hz}, 2 \mathrm{H}), 2.34$ (quin, $J=7.6 \mathrm{~Hz}, 2 \mathrm{H}$ ). ${ }^{13} \mathrm{C} \mathrm{NMR}$ $\left(\mathrm{CDCl}_{3}, 100 \mathrm{MHz}\right): \delta=169.6,142.6,140.1,140.0,139.3,135.0,131.6,131.0,128.9$, 127.8, 127.6, 127.5, 127.1, 126.1, 125.3, 125.2, 125.0, 123.2, 32.9, 32.5, 26.7. HRMS (ESI) $m / z$ : Calculated for $\mathrm{C}_{26} \mathrm{H}_{15} \mathrm{~F}_{5} \mathrm{O}_{2} \mathrm{Na}[\mathrm{M}+\mathrm{Na}]^{+}$: 477.0885; found: 477.0881 .

\section{Ethyl 2-(4-(4-(pyren-1-yl)butanoyl)piperazin-1-yl)acetate 5:}

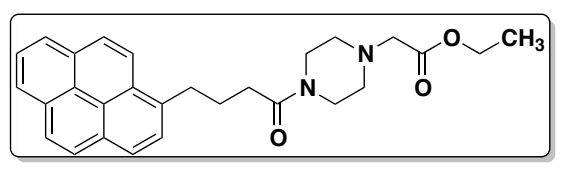

Ethyl 2-(piperazin-1-yl)acetate $4^{2}(0.33 \mathrm{mmol}, 56$ $\mathrm{mg})$ and activated pentafluorophenyl ester $3(0.3$

mmol, $0.14 \mathrm{~g}$ ) was taken in dichloromethane and the mixture reaction was stirred at room temperature. Diisopropyl ethylamine $(0.6 \mathrm{mmol}, 0.10 \mathrm{~mL})$ was added to it. The reaction mixture was stirred until completion of the reaction $(2.5 \mathrm{hrs}$, monitored by TLC). After completion of the reaction, the mixture was diluted with dichloromethane and washed with water $(1 \times 15 \mathrm{~mL})$. Organic extracts were dehydrated with anhydrous sodium sulfate and evaporated to give crude products, which were purified by silica gel chromatography using $1-2 \%$ methanol in chloroform as eluents. The desired product was isolated as a colorless sticky liquid $(86 \%, 0.12 \mathrm{~g}) .{ }^{1} \mathrm{H}$ NMR $\left(\mathrm{CDCl}_{3}, 400 \mathrm{MHz}\right): \delta=8.33(\mathrm{~d}, J=9.6 \mathrm{~Hz}, 1 \mathrm{H}), 8.16(\mathrm{~d}, J=7.2 \mathrm{~Hz}, 1 \mathrm{H}), 8.15(\mathrm{~d}, J=$ $7.6 \mathrm{~Hz}, 1 \mathrm{H}), 8.10(\mathrm{~d}, J=8.4 \mathrm{~Hz}, 2 \mathrm{H}), 8.04(\mathrm{~s}, 2 \mathrm{H}), 7.98$ (t, $J=8.0 \mathrm{~Hz}, 1 \mathrm{H}), 7.86(\mathrm{~d}, J$ $=8.0 \mathrm{~Hz}, 1 \mathrm{H}), 4.17(\mathrm{q}, J=7.6 \mathrm{~Hz}, 2 \mathrm{H}), 3.71(\mathrm{t}, J=4.8 \mathrm{~Hz}, 2 \mathrm{H}), 3.43-3.37$ (cluster, 4H), $3.19(\mathrm{~s}, 2 \mathrm{H}), 2.56(\mathrm{t}, J=5.0 \mathrm{~Hz}, 2 \mathrm{H}), 2.47(\mathrm{t}, J=5.0 \mathrm{~Hz}, 2 \mathrm{H}), 2.39(\mathrm{t}, J=7.2 \mathrm{~Hz}$, 2H), 2.21 (quin, $J=6.8 \mathrm{~Hz}, 2 \mathrm{H}), 1.26(\mathrm{t}, J=7.6 \mathrm{~Hz}, 3 \mathrm{H}) .{ }^{13} \mathrm{C} \mathrm{NMR}\left(\mathrm{CDCl}_{3}, 100\right.$ $\mathrm{MHz}): \delta=171.2,169.9,136.1,131.4,130.9,129.9,128.9,127.5,127.4,126.7,125.9$, 
$125.1,125.0,124.9,124.8,124.8,123.5,60.9,59.0,52.8,52.6,45.1,41.3,32.8,32.4$, 26.9, 14.3. HRMS (ESI) $m / z$ : Calculated for $\mathrm{C}_{28} \mathrm{H}_{30} \mathrm{~N}_{2} \mathrm{O}_{3} \mathrm{Na}[\mathrm{M}+\mathrm{Na}]^{+}:$465.2144; found: 465.2139 .

Perfluorophenyl 2-(4-(4-(pyren-1-yl)butanoyl)piperazin-1-yl)acetate

6:

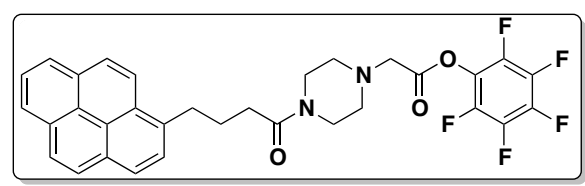

Compound 5 (0.26 mmol, $0.12 \mathrm{~g})$ was dissolved in $5 \mathrm{~mL}$ dichloromethane and $2 \mathrm{~N} \mathrm{NaOH}$ in methanol $(1 \mathrm{~mL})$ was added to it. The reaction mixture was stirred until completion of the reaction ( 2 hrs, monitored by TLC). Solvents were evaporated to provide white colored solids which were the sodium salt of desired carboxylic acid (confirmed by mass spectroscopy). The reaction mixture was made acidic by using $4 \mathrm{~N} \mathrm{HCl}$ in ethyl acetate and later the solvent was evaporated completely to give while solids, which were dried under vacuum. Assuming quantitative conversion, crude products were used as such for the activation step. The solid acids were suspended in $5 \mathrm{~mL}$ dry dimethyl formamide and excess triethylamine was added to it. To this stirring mixture pentafluorophenyl trifluoroacetate $(0.77 \mathrm{mmol}, 0.11 \mathrm{~mL})$ was added drop wise. The reaction mixture was stirred at room temperature until completion $(3 \mathrm{hrs}$, monitored by TLC). After completion, solvents were evaporated completely under vacuum and crude residue was purified by silica gel column chromatography using 1-2\% methanol in chloroform as eluents to give a desired product as white solids (yield 80\%, $0.12 \mathrm{~g}$ ). ${ }^{1} \mathrm{H}$ NMR $\left(\mathrm{CDCl}_{3}, 600 \mathrm{MHz}\right): \delta=8.32(\mathrm{~d}, J=10.2 \mathrm{~Hz}, 1 \mathrm{H}), 8.16(\mathrm{~d}, J=8.4 \mathrm{~Hz}, 1 \mathrm{H})$, 8.11-8.09 (cluster, 2H), $8.02(\mathrm{dd}, J=12.0 \mathrm{~Hz}, 9.0 \mathrm{~Hz}, 2 \mathrm{H}), 7.98(\mathrm{t}, J=5.4 \mathrm{~Hz}, 1 \mathrm{H})$, $7.86(\mathrm{t}, J=7.8 \mathrm{~Hz}, 1 \mathrm{H}), 3.72(\mathrm{t}, J=4.8 \mathrm{~Hz}, 2 \mathrm{H}), 3.56(\mathrm{bs}, 2 \mathrm{H}), 3.42(\mathrm{t}, J=7.8 \mathrm{~Hz}$, 2H), $3.38(\mathrm{t}, J=4.8 \mathrm{~Hz}, 2 \mathrm{H}), 2.64(\mathrm{t}, J=4.8 \mathrm{~Hz}, 2 \mathrm{H}), 2.54(\mathrm{t}, J=4.8 \mathrm{~Hz}, 2 \mathrm{H}), 2.40(\mathrm{t}$, $J=7.2 \mathrm{~Hz}, 2 \mathrm{H}), 2.23(\mathrm{tt}, J=4.4 \mathrm{~Hz}, 5.2 \mathrm{~Hz}, 2 \mathrm{H}) .{ }^{13} \mathrm{C} \mathrm{NMR}\left(\mathrm{CDCl}_{3}, 150 \mathrm{MHz}\right): \delta=$ $171.3,165.9,140.2,138.8,137.1,136.0,131.5,130.9,130.2,128.9,127.5,127.4$ $126.8,125.9,125.1,125.0,124.8,124.8,123.5,57.9,52.3,52.2,45.2,41.4,32.8$, 
32.3, 26.9. HRMS (ESI) $m / z$ : Calculated for $\mathrm{C}_{32} \mathrm{H}_{25} \mathrm{~F}_{5} \mathrm{~N}_{2} \mathrm{O}_{3} \mathrm{Na}[\mathrm{M}+\mathrm{Na}]^{+}$: 603.1674; found: 603.1670 .

tert-butyl

(3-((7-((3-(2-(4-(4-(pyren-1-yl)butanoyl)piperazin-1-

yl)acetamido)propyl)amino)-1,8-naphthyridin-2-yl)amino)propyl)carbamate

(BocPyDANP) 10: Protected dibocDANP $7(0.15 \mathrm{mmol}, 71 \mathrm{mg})$, was de-protected as

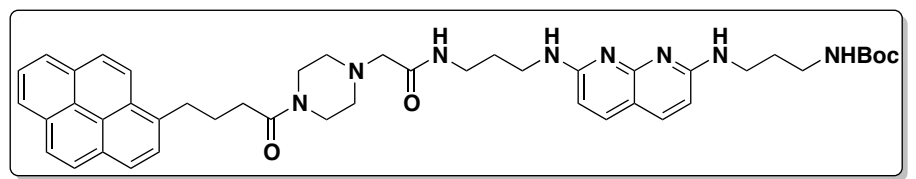

described earlier to give DANP hydrochloride salt $\mathbf{8}$.

The salt was suspended in $4 \mathrm{~mL}$ dichloromethane and excess diisopropylethylamine was added to it. After keeping the mixture stirred for $5 \mathrm{~min}$, a mixture of activated pentafluorophenyl ester $6(0.17 \mathrm{mmol}, 99 \mathrm{mg})$ and Boc anhydride $(0.17 \mathrm{mmol}, 38 \mu \mathrm{L})$ in a mixture of dichloromethane and dimethyl formamide $(4 \mathrm{~mL}$ and $2 \mathrm{~mL}$, respectively), was added to it. The reaction mixture was kept on room temperature stirring until completion of the reaction ( $4 \mathrm{hrs}$, monitored by TLC). The reaction mixture consisted of 3 major products, which included our desired Boc-protected PyDANP 10, Boc-protected DANP 7 and bispyrene DANP 9. After completion of the reaction, solvents were evaporated completely under vacuum and crude products were purified by column chromatography on amine silica gel using $50 \%$ ethyl acetatehexane followed by $2-4 \%$ methanol-ethyl acetate as eluents. The desired product was isolated as yellowish solids (35 mg, 30\%). ${ }^{1} \mathrm{H}$ NMR $\left(\mathrm{CDCl}_{3}, 400 \mathrm{MHz}\right): \delta=8.31(\mathrm{~d}, J$ $=9.6 \mathrm{~Hz}, 1 \mathrm{H}), 8.15(\mathrm{dd}, J=7.6 \mathrm{~Hz}, 2.4 \mathrm{~Hz}, 2 \mathrm{H}), 8.10-8.08$ (cluster, 2H), 8.01 (bs, 2 H), $7.98(\mathrm{t}, J=7.2 \mathrm{~Hz}, 1 \mathrm{H}), 7.84(\mathrm{~d}, J=8.0 \mathrm{~Hz}, 1 \mathrm{H}), 7.51-7.40$ (cluster, 3H), 6.33 (d, $J=8.8 \mathrm{~Hz}, 1 \mathrm{H}), 6.29(\mathrm{~d}, J=8.8 \mathrm{~Hz}, 1 \mathrm{H}), 5.88(\mathrm{bs}, 1 \mathrm{H}), 5.23(\mathrm{bs}, 1 \mathrm{H}), 3.67(\mathrm{bs}, 2 \mathrm{H})$, 3.54-3.44 (cluster, 4H), 3.41-3.36 (cluster 4H), 3.18 (q, $J=6.0 \mathrm{~Hz}, 2 \mathrm{H}), 3.02(\mathrm{~s}, 2 \mathrm{H})$, $2.46(\mathrm{t}, J=4.8 \mathrm{~Hz}, 2 \mathrm{H}), 2.37-2.33$ (cluster $4 \mathrm{H}), 2.18(\mathrm{tt}, J=7.2 \mathrm{~Hz}, 8.0 \mathrm{~Hz}, 2 \mathrm{H}), 1.82$ $(\mathrm{tt}, J=5.6 \mathrm{~Hz}, 7.6 \mathrm{~Hz}, 2 \mathrm{H}), 1.73(\mathrm{tt}, J=6.0 \mathrm{~Hz}, 6.4 \mathrm{~Hz}, 2 \mathrm{H}), 1.42(\mathrm{~s}, 9 \mathrm{H}) .{ }^{13} \mathrm{C} \mathrm{NMR}$ $\left(\mathrm{CDCl}_{3}, 100 \mathrm{MHz}\right): \delta=171.1,170.0,159.0,156.5,137.6,136.1,131.4,130.9,129.9$ 
$128.9,127.6,127.4,126.8,125.9,125.1,125.0,124.8,123.5,110.1,61.5,53.4,53.2$, 45.3, 41.5, 38.6, 38.5, 37.6, 36.3, 32.8, 32.4, 30.1, 29.5, 285, 26.9. HRMS (ESI) $m / z$ : Calculated for $\mathrm{C}_{45} \mathrm{H}_{54} \mathrm{~N}_{8} \mathrm{O}_{4}[\mathrm{M}+\mathrm{H}]^{+}:$771.4326; found: 771.4338 .

PyDANP hydrochloride salt, 11: Boc-protected PyDANP, 10 was dissolved in 5 (n) $\mathrm{mL}$ dichloromethane and $1 \mathrm{~mL}$ of $4 \mathrm{M} \mathrm{HCl}$ dissolved in ethyl

acetate was added to in drop wise manner under ice cooling. A yellowish solid started to form very quickly. The reaction was stirred at room temperature until completion of reaction ( 2 hrs, monitored by TLC). After completion of the reaction the solvents were evaporated completely under vacuum and crude solids were suspended in dry dichloromethane. The un-dissolved solids were filtered and washed 2-3 times with dry diethyl ether to give the desired compound as yellowish salts (29 mg, 66\%). The compound was further purified by HPLC to afford the pure compound for further studies. ${ }^{1} \mathrm{H}$ NMR $\left(\mathrm{CD}_{3} \mathrm{OD}, 400 \mathrm{MHz}\right): \delta=8.34(\mathrm{~d}, J=9.2 \mathrm{~Hz}, 1 \mathrm{H}), 8.18(\mathrm{~d}, J=7.6$ $\mathrm{Hz}, 1 \mathrm{H}), 8.17(\mathrm{~d}, J=8.0 \mathrm{~Hz}, 1 \mathrm{H}), 8.13(\mathrm{~d}, J=8.0 \mathrm{~Hz}, 1 \mathrm{H}), 8.12(\mathrm{~d}, J=9.2 \mathrm{~Hz}, 1 \mathrm{H})$, $8.03(\mathrm{bs}, 2 \mathrm{H}), 7.98(\mathrm{t}, J=7.6 \mathrm{~Hz}, 1 \mathrm{H}), 7.88(\mathrm{~d}, J=8.0 \mathrm{~Hz}, 1 \mathrm{H}), 7.56(\mathrm{~d}, J=8.8 \mathrm{~Hz}$, 1H), $7.55(\mathrm{~d}, J=8.8 \mathrm{~Hz}, 1 \mathrm{H}), 6.44(\mathrm{~d}, J=8.8 \mathrm{~Hz}, 1 \mathrm{H}), 6.41(\mathrm{~d}, J=8.4 \mathrm{~Hz}, 1 \mathrm{H}), 3.59$ $3.56(\mathrm{~m}, 4 \mathrm{H}), 3.46(\mathrm{t}, J=6.8,2 \mathrm{H}), 3.41-3.31$ (cluster, 6H), $2.95(\mathrm{bs}, 4 \mathrm{H}), 2.46-2.40$ (cluster, 4H), 2.32 (t, $J=4.4 \mathrm{~Hz}, 2 \mathrm{H}), 2.12$ (quin, $J=7.6 \mathrm{~Hz}, 2 \mathrm{H}), 1.98-1.90$ (m, 9H), $1.85(\mathrm{t}, J=6.8 \mathrm{~Hz}, 2 \mathrm{H}) .{ }^{13} \mathrm{C} \mathrm{NMR}\left(\mathrm{CD}_{3} \mathrm{OD}, 100 \mathrm{MHz}\right): \delta=173.7,172.7,161.6$, $161.2,157.5,138.8,138.3,137.4,132.9,132.3,131.4,130.1,128.7,128.6,128.5$, $127.8,127.1,126.3,126.2,126.1,126.0,125.9,124.5,111.1,108.3,62.0,54.3,54.0$, $46.5,42.7,39.8,38.2,37.9,37.6,33.6,33.3,30.3,30.0,28.5,23.0$. HRMS (ESI) $m / z$ : Calculated for $\mathrm{C}_{40} \mathrm{H}_{46} \mathrm{~N}_{8} \mathrm{O}_{2}[\mathrm{M}+\mathrm{H}]^{+}:$671.3804; found: 671.3802 . 
Synthesis of pyrene reference compound PyL:
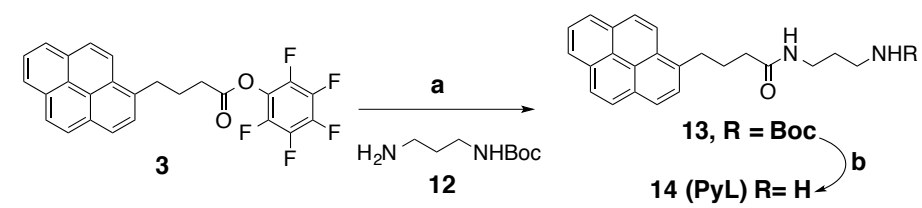

Figure S2: Synthetic scheme for ligand PyL: a) Diisopropylethylamine / dichloromethane / rt / $2.5 \mathrm{~h}$, $86 \%$; b) $4 \mathrm{M} \mathrm{HCl}$ in ethylacetate / dichloromethane / rt / 3 h, quantitative

\section{Absorption spectra of PyDANP with decreasing temperature from 85 to $2{ }^{\circ} \mathrm{C}$ :}

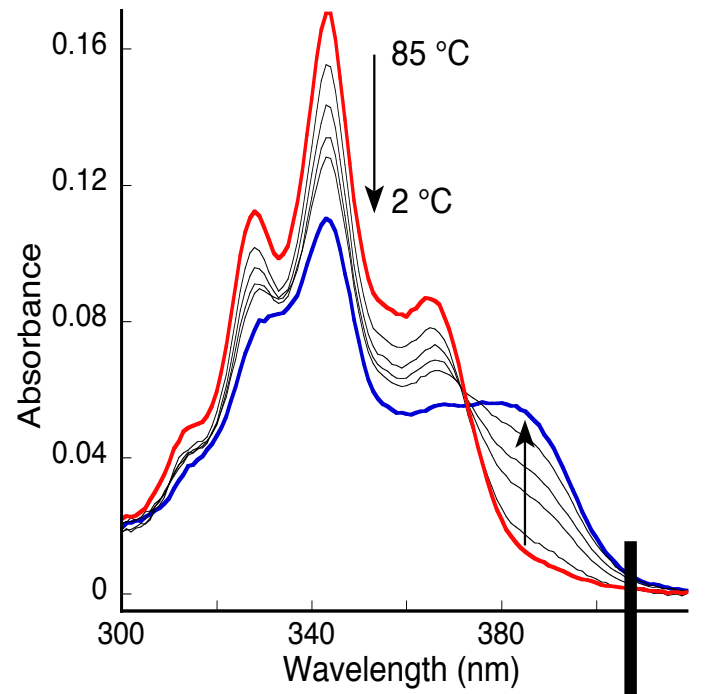

Figure S3: UV absorption spectra of PyDANP with decreasing temperature from $85^{\circ} \mathrm{C}$ (Red line) to 2 ${ }^{\circ} \mathrm{C}$ (Blue line)

\section{Absorption spectrum of PyDANP with increasing methanol percentage:}

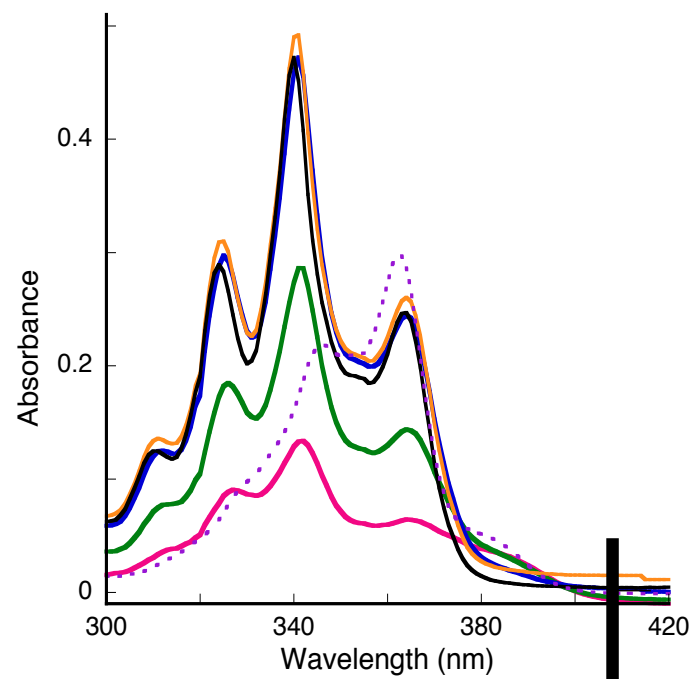

Figure S4: Absorption spectra of PyDANP with increasing methanol percentage. Pink line $(0 \%$ $\mathrm{MeOH})$, Green line $(25 \% \mathrm{MeOH})$, Blue line $(50 \% \mathrm{MeOH})$, Yellow line $(75 \% \mathrm{MeOH})$, Black line $(100 \% \mathrm{MeOH})$ and Violet dotted line (DANP in $100 \% \mathrm{MeOH}) .10 \mu \mathrm{M}$ solutions of respective ligands were prepared in $10 \mathrm{mM}$ sodium cacodylate buffer ( $\mathrm{pH}$ 7.0) containing $100 \mathrm{mM}$ sodium chloride. 


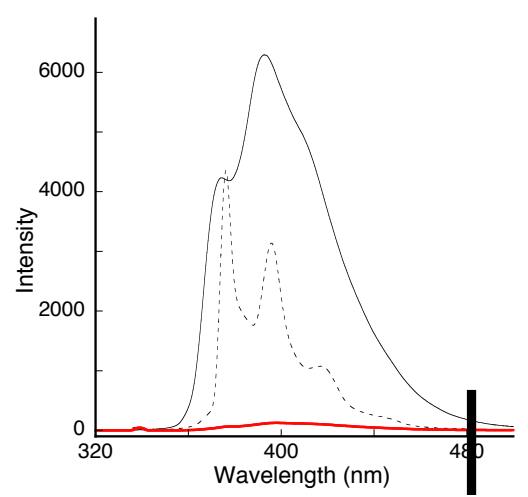

Figure S5: Fluorescence spectra of $10 \mu \mathrm{M}$ PyDANP (red line), DANP (solid balck line), and PyL (Dotted black line) in $10 \mathrm{mM}$ sodium cacodylate buffer (pH 7.0) containing $100 \mathrm{mM}$ sodium chloride. Excitation wavelengths are $340 \mathrm{~nm}$ (PyL), $343 \mathrm{~nm}$ (PyDANP), and $362 \mathrm{~nm}$ (DANP).

\section{Concentration dependent absorption spectra of PyDANP}

Concentration dependent UV and fluorescence spectra of PyDANP didn't show any change in the shape and structure with increasing concentration (Figure S6a). The absorbance vs conc. plots give the linear curves at major absorption maxima (Figure S6b-c). The absorption spectra of PyL, DANP and a mixture of PyL and DANP are superimposable. PyDANP has completely different spectra at same concentration (Figure S6d). We have also performed the dilution experiments at $2{ }^{\circ} \mathrm{C}$. The results showed no changes in shape and structure of spectra with increasing conc. and absorbance change at $375 \mathrm{~nm}$ is linear (Figure S6e-f).
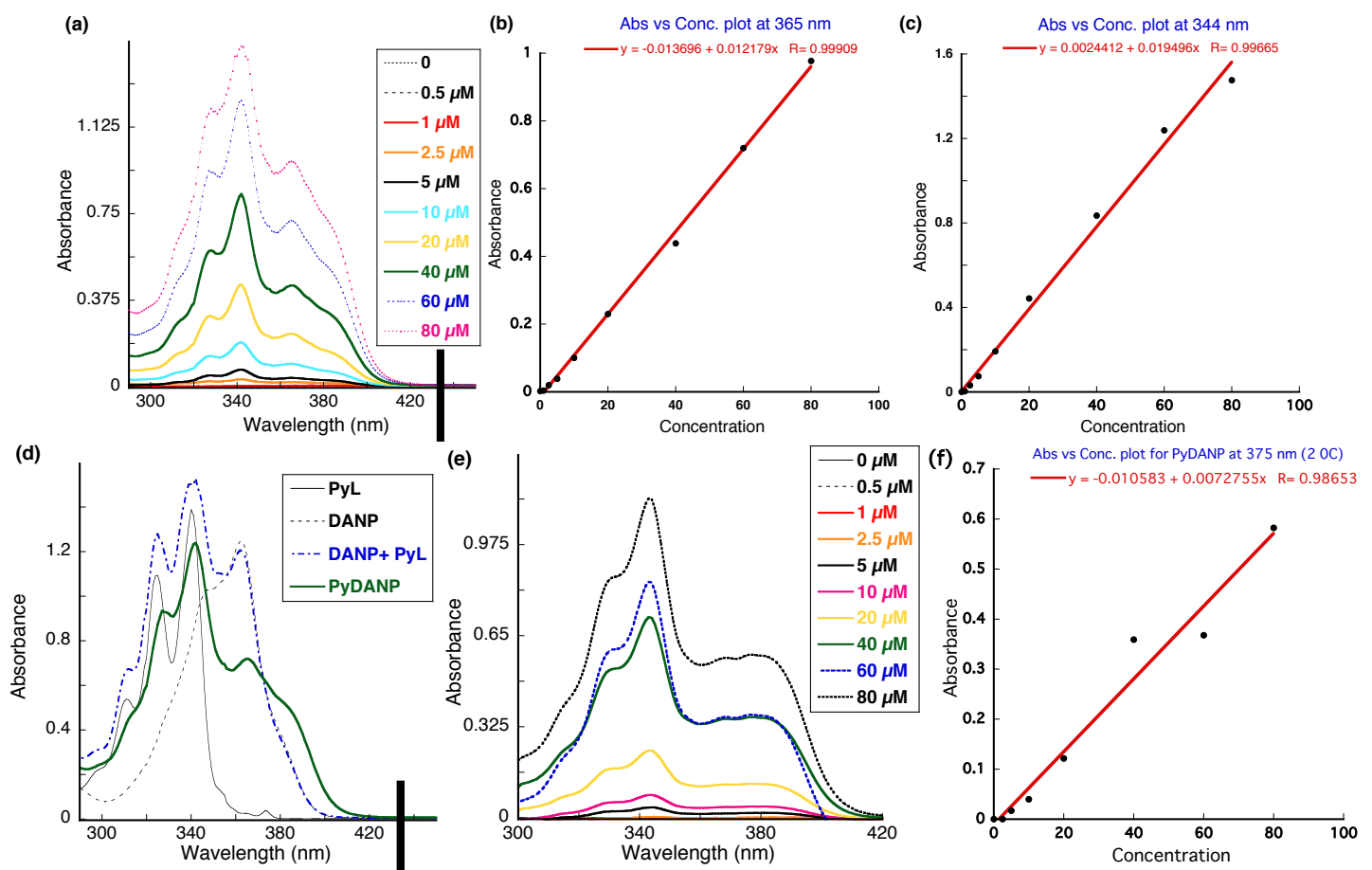

Figure S6: Absorption spectra of PyDANP. (a) With increasing concentration. (b) Plot of absorbance vs conc. at $\lambda$ max $365 \mathrm{~nm}$. (c) Plot of absorbance vs conc. at $\lambda \max 344 \mathrm{~nm}$. (d) Comparative absorption spectra of ligands PyL, DANP, PyDANP and mixture of DANP and PyL at $60 \mu \mathrm{M}$ concentration. (e) Absorption spectra of PyDANP with increasing conc. at $2{ }^{\circ} \mathrm{C}$. (f) Plot of absorbance vs conc. at $\lambda \max 375 \mathrm{~nm}$ at $2{ }^{\circ} \mathrm{C}$. 


\section{Concentration dependent fluorescence spectra of PyDANP}

Fluorescence spectra of PyDANP showed a linear increase of fluorescence intensity with increasing concentration. (Figure S7a-b).
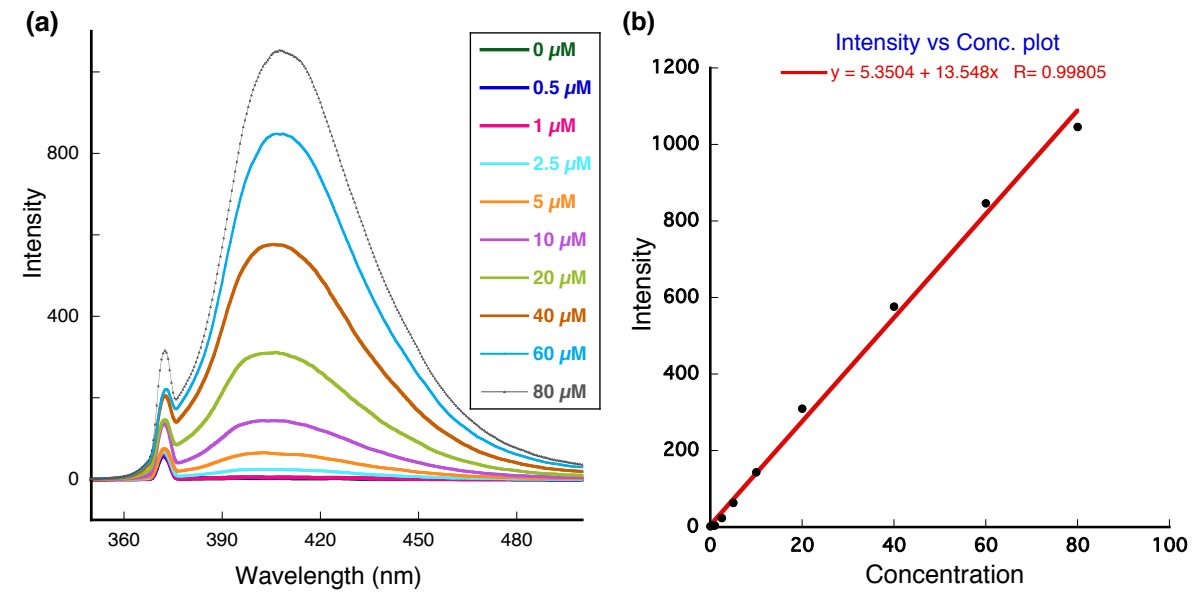

Figure S7: Fluorescence spectra of PyDANP. (a) With increasing concentration. (b) Plot of fluorescence vs concentration. All solutions were prepared in $10 \mathrm{mM}$ sodium cacodylate buffer $(\mathrm{pH}$ 7.0) containing $100 \mathrm{mM}$ sodium chloride. Excitation wavelength is $375 \mathrm{~nm}$ for fluorescence measurement.

\section{Concentration dependent absorption and fluorescence spectra of PyL}

There are no change in structure of absorption and emission spectra of PyL (Figure S8a-b). Characteristic eximer emission at $\sim 475 \mathrm{~nm}$ for pyrene-pyrene stacking was not observed.
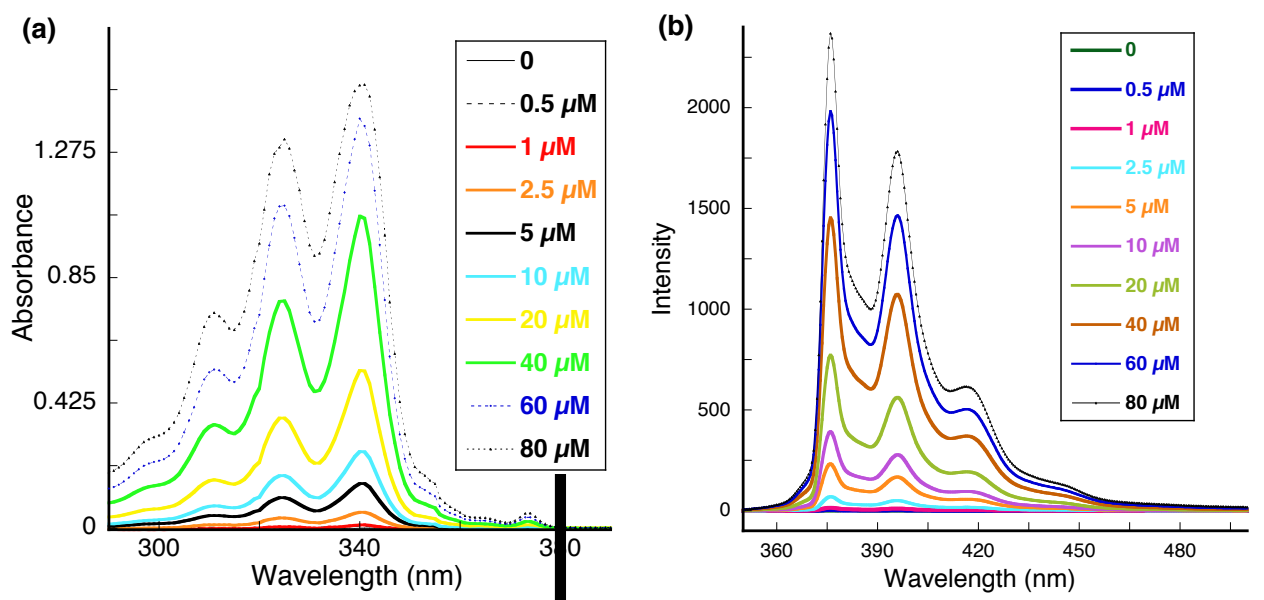

Figure S8: (a) Absorption spectra of PyL with increasing concentration. (b) Fluorescence spectra of PyL with increasing concentration. All solutions were prepared in $10 \mathrm{mM}$ sodium cacodylate buffer (pH 7.0) containing $100 \mathrm{mM}$ sodium chloride. Excitation wavelength is $340 \mathrm{~nm}$ for fluorescence measurement. 


\section{Concentration dependent absorption and fluorescence spectra of DANP}

There are no change in shape and structure of absorption/emission spectra of DANP and fluorescence increases with concentration (Figure S9a-b).
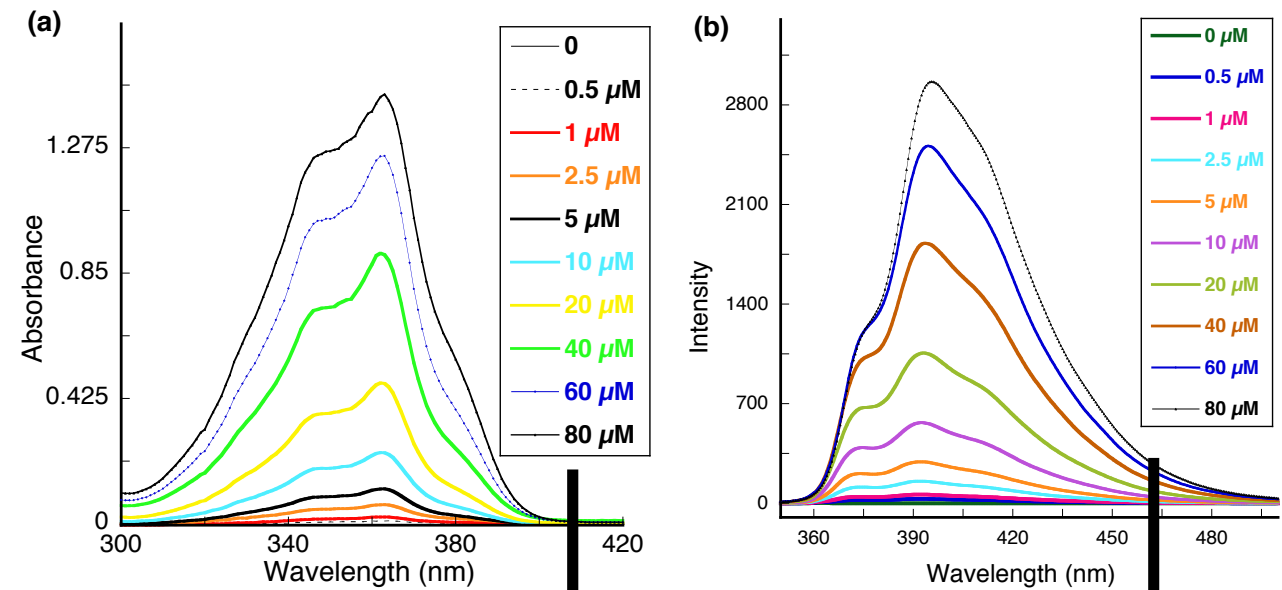

Figure S9: (a) Absorption spectra of DANP with increasing concentration. (b) Fluorescence spectra of DANP with increasing concentration. All solutions were prepared in $10 \mathrm{mM}$ sodium cacodylate buffer (pH 7.0) containing $100 \mathrm{mM}$ sodium chloride. Excitation wavelength is $365 \mathrm{~nm}$ for fluorescence measurement.

\section{Concentration dependent absorption and fluorescence spectra of PyL + DANP}

An equimolar mixture of PyL and DANP did not undergo any change in shape and structure of absorption and emission spectra. It is a simple mixture of both component chromophores at all concentrations.
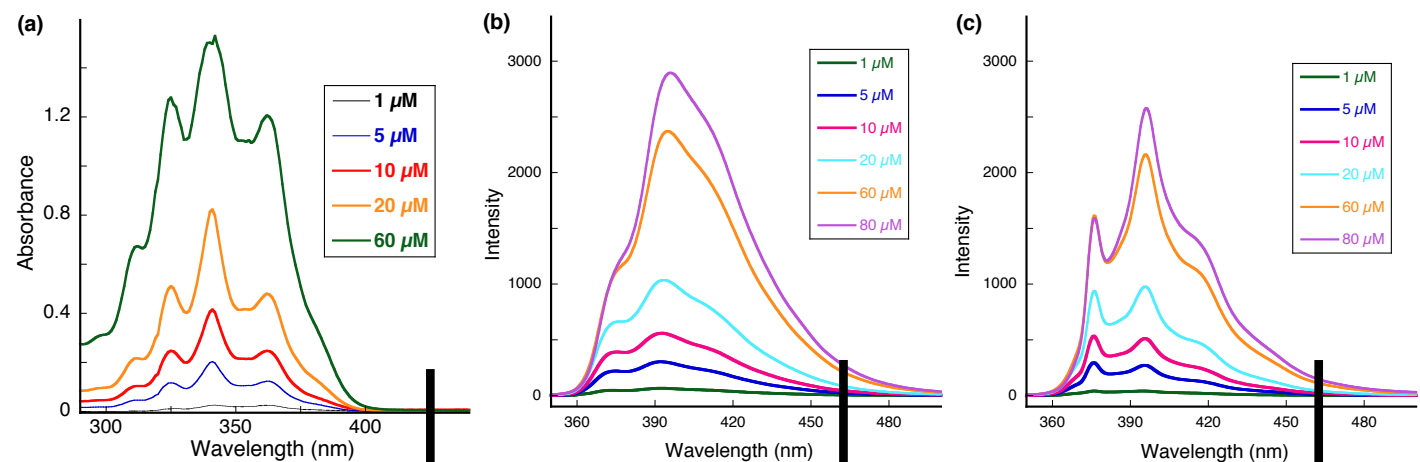

Figure S10: (a) Absorption spectra of equimolar mixture of PyL and DANP. (b) Fluorescence spectra of equimolar mixture of PyL and DANP excited at $365 \mathrm{~nm}$ (DANP absorption maxima). (c) Fluorescence spectra of equimolar mixture of PyL and DANP excited at $340 \mathrm{~nm}$ (PyL absorption maxima). All solutions were prepared in $10 \mathrm{mM}$ sodium cacodylate buffer (pH 7.0) containing 100 mM sodium chloride. 
Absorption spectra of ligand PyL in presence of c-bulge hairpin DNA

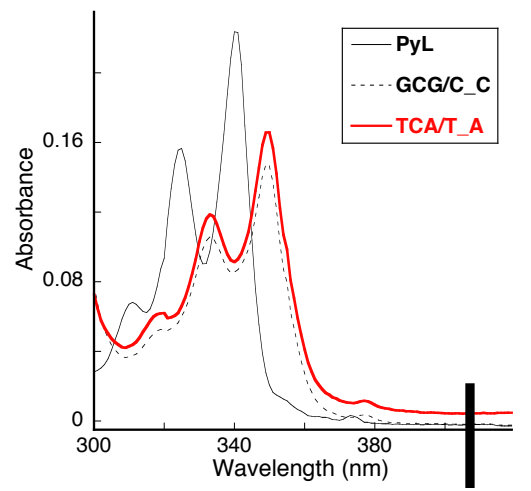

Figure S11: Absorption spectra of ligand PyL showing $\sim 10 \mathrm{~nm}$ shift indicating pyrene interaction with DNA. $10 \mu \mathrm{M}$ ligand and $10 \mu \mathrm{M}$ DNA solutions were prepared in $10 \mathrm{mM}$ sodium cacodylate buffer (pH 7.0) containing $100 \mathrm{mM}$ sodium chloride.

\section{References:}

1. K. C. Etika, F. D. Jochum, M. A. Cox, P. Schattling, P. Theato, J. C. Grunlan, Macromolecules, 2010, 43, 9447.

2. K. S. Putt, G.W. Chen, J. M. Pearson, J. S. Sandhorst, M. S. Hoagland, J.-T. Kwon, S.-K. Hwang, H. Jin, M. I. Churchwell, M.-H. Cho, D. R. Doerge, W. G. Helferich, P. J. Hergenrother, Nat. Chem. Biol. 2006, 2, 543. 
${ }^{1} \mathrm{H}$ and ${ }^{13} \mathrm{C}$ NMR spectrum for compound 3
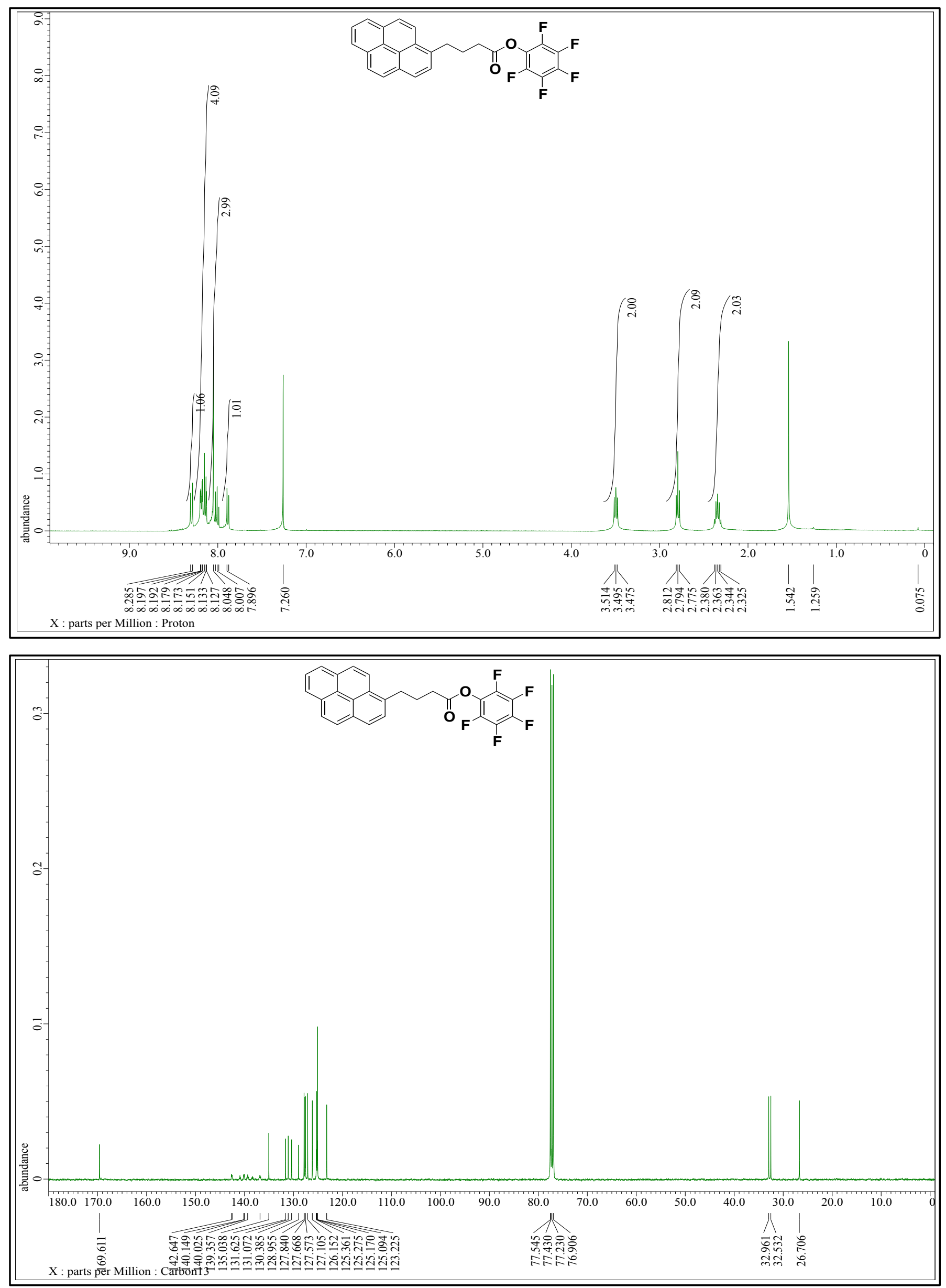
${ }^{1} \mathrm{H}$ and ${ }^{13} \mathrm{C}$ NMR spectrum for compound 5
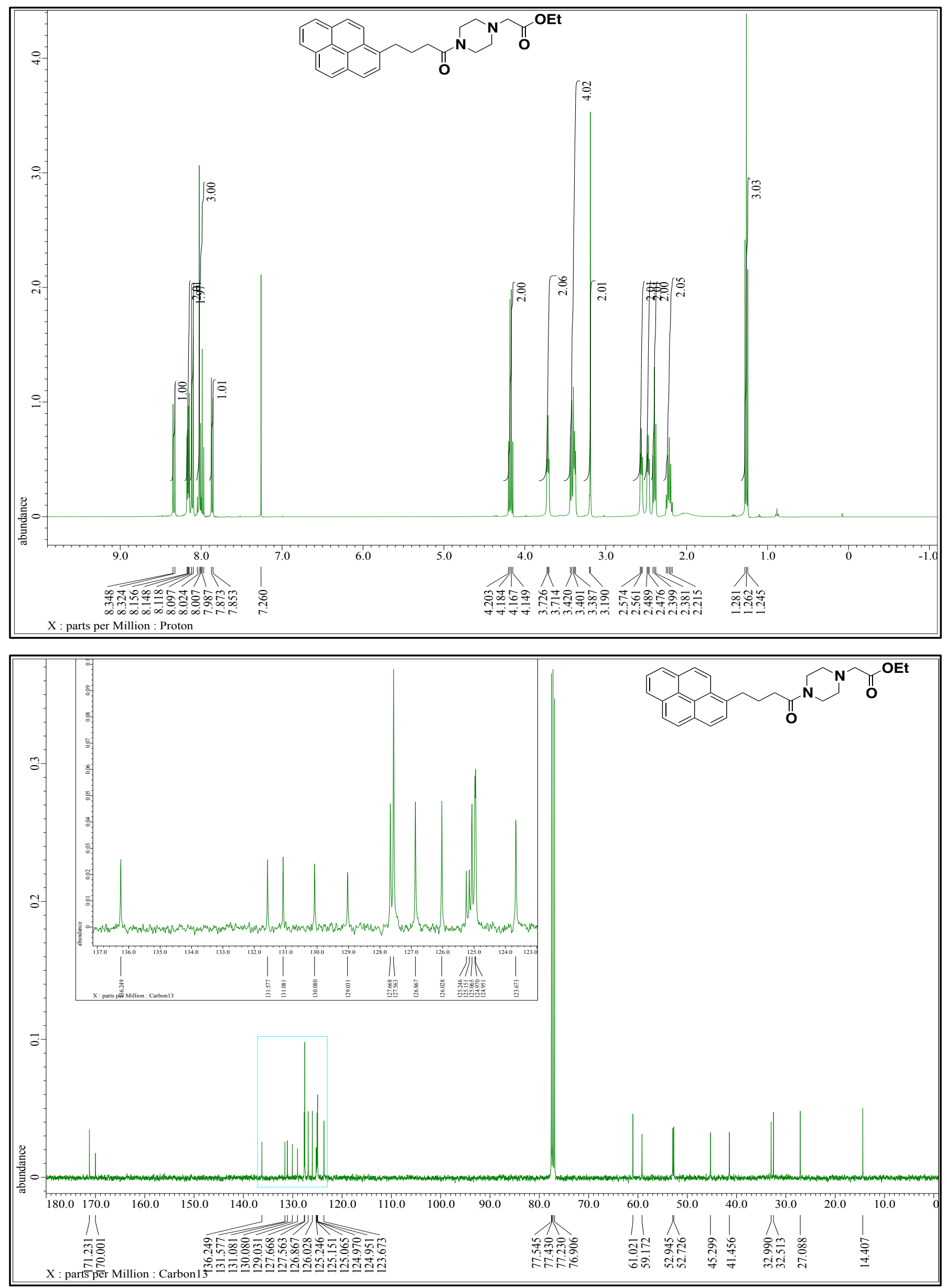
${ }^{1} \mathrm{H}$ and ${ }^{13} \mathrm{C}$ NMR spectrum for compound 6
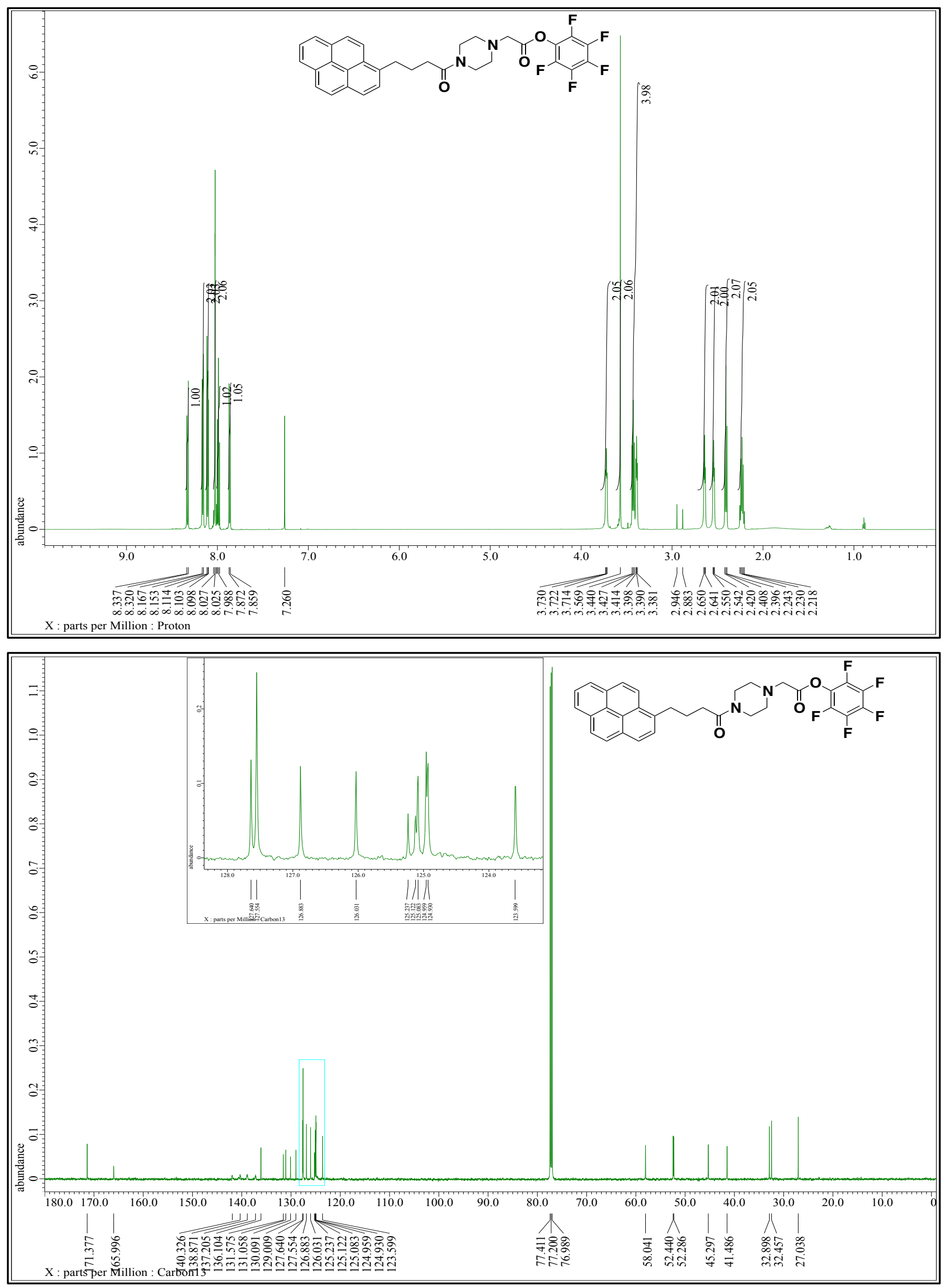

S16 
${ }^{1} \mathrm{H}$ and ${ }^{13} \mathrm{C}$ NMR spectrum for compound 10
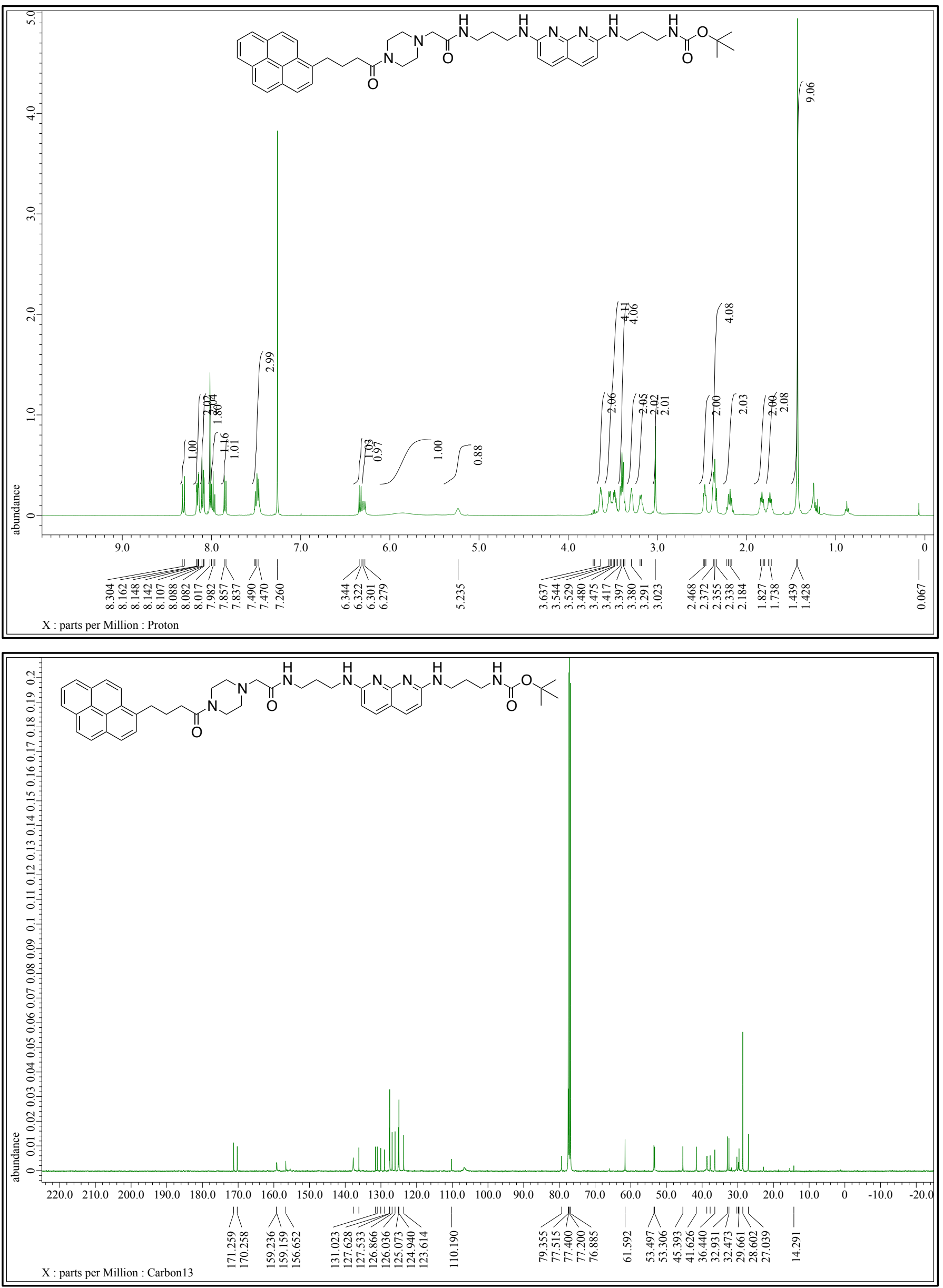
${ }^{1} \mathrm{H}$ and ${ }^{13} \mathrm{C}$ NMR spectrum for compound 11
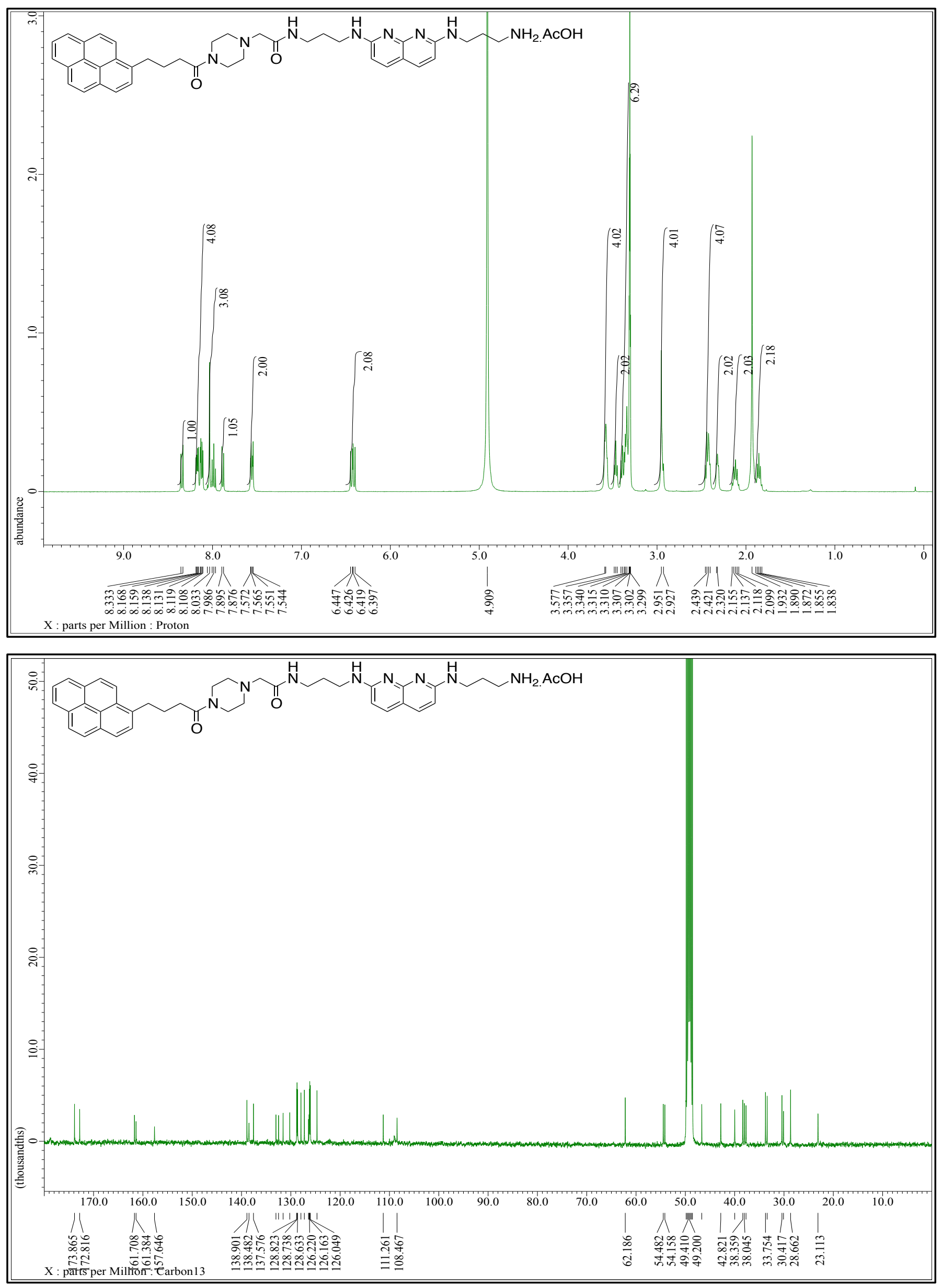

S18 